amongst the admissions of 1871. By way of illustration, let me state that at Hanwell, in 1871, the percentage of "recoveries on admission," calculated according to the official tables, is stated at 23.3 ; but on turning to Table 6 it appears that 28 patients had not been admitted in 1871 , but had been in the asylum for terms varying from two to twelve years.

It follows, from these tables, that the percentage of cures will vary, not according to the recoveries effected, but as the admissions are few or many; if few, the ratio will be high, if many, the ratio will be low; and if from any cause there should be a suspension of admissions, but the ordinary number of recoveries effected, the Commissioners in Lunacy would have to invent a new formula to calculate the cures.

The official tables adopt a different base for the mortality of an asylum, and the deaths are properly calculated on the average number resident in the asylum. How both bases can be correct is difficult to account for.

It was an epigrammatic remark of Canning's, that he "always distrusted 'facts and figures," and $I$ think that the table sanctioned by the Commissioners in Lunacy should be revised without delay.

I am, Sir, your obedient servant, P. Northatl LaURit.

Pax-hill Park, Lindfield, Ang. 26th, 1872.

\section{VERSION AND UTERINE TETANUS.}

\section{To the Editor of THE LANCET.}

Srr,-A paper by Dr. Milne, of Edinburgh, in Tre LANCET of August 10th, appears to me to call for a few re. marks. And, first, I must take exception to the term "uterine tetanus," which I venture to think is not happily chosen, as it associates the state in question with a disease with which I think it can hardly be said to have any affinities, however remote, and which is usually defined by our best medical writers as affecting voluntary muscles only. I think, therefore, bis other term, "tonic contraction," or "tonic spasm," to be infinitely preferable, both from the positive merit of describing accurately the nature of the contraction, and from the negative but not less important merit of conveying no false impressions.

But the real object of this letter is not to find fault with Dr. Milne's terminology, but to elicit some information bearing on the question, "Shall we seize one leg or both?" The principal reasnns for seizing one foot only are briefly these:--The child's life is more frequently preserved (by prevention of pressure on the funis) in half-breech cases, than in footlings; and the greater bulk of the half-breech dilates the cervix better than the hips do, and so facilitates the extraction of the head. Here, then, are obvious advantages in favonr of the half-breech. Its disadvantage, according to $\mathrm{Dr}$. Milne, is that it cannot always be effective, that the turning is more likely to be ascomplished if both feet are brought down; and he gives two cases to prove his point (Cases 3 and 6 in his paper), but in both he makes an omission which, in my eyes, is fatal to his argument. He does not tell us in either case which arm presented, nor which foot was brought down. The obvious inference is, not that he failed to turn because he did not bring down both legs, but that he did so because he brought down the wrong one-i.e., the one belonging to the same side as the presenting arm. This is a matter of no small importance; for, looking at the case from a purely physical point of view, it is manifest that to produce the greatest effect on one end of the body, or in other words to turn with the expenditure of the least amount of force, you must apply that force to the best advantage, and ordinary mechanical principles will point out that the proper place to apply the force in order to obtain this result is the part directly opposite to that presenting-namely, the lower extremity belonging to the opposite side. For a full detail of the principles on which this is done I take leave to refer your readers to a paper on Turning by the late Sir J. Y. Simpson, in the London and Edinburgh Monthly Journal of Medical Science, Felruary, 1845.

I am, Sir, your obedient servant, Edgar G. Barnes, M.B. Lond.

\section{THE ARMY MEDICAL SERVICE.}

\section{To the Editor of The LaNcert.}

Sir, -I am sorry to see that no examination of candidates for the Army Medical Department will be held this month, because the department is at present undermanned and over-worked. As an example, passing through Malta, of the sanitary condition of which you had a very mild description the other day, I found that three medical officers had been invalided, three others were on the sick-list (three regiments being in charge of assistantsurgeons), and still worse, that no one had been, or was likely to be, on leave during the year. It is a case of " all work and no play" there; so it is generally. Can we be otherwise than dull? Not even the prospect of promotion to enliven us. Looking at Hart's Quarterly List, I see there are-

10 inspectors-general, with an average service as assistant-surgeon of 34 deputy-inspectors-general, 94 surgeons-major,

ditto 8 yrs, $\frac{1}{2}$ math. 26 surgeons, entered prior to 1854, ditto 8 yrs. 9 mos. 62 ditto Jan. to June, 1854, ditto 11 yrs. 1 mos. 43 ditto July to Dec., 1854, ditto 12 yrs. $8 \frac{1}{2}$ mos.

Average time $\quad \ldots \quad \ldots \quad 10$ yrs. $3 \frac{2}{s}$ mos.

(The remainder have no chance of ever reaching the inspectorial rank, as the age disqualification must apply to them, as it probably will to the last 43.)

Now, as it is from these numbers that the higher ranks will be appointed during the next twenty years, would it be too much to expect that the present assistant-surgeons should be promoted at twelve years' service, seeing they can never attain higher rank than that of surgeon or surgeon-major? It is too bad, I think, that those who entered the service ten years ago, expeeting promotion as hitherto in the course of eight or nine years, should still be likely to remain the same length of time in the position of "subaltern" doctors. It may be said that we are as well paid as surgeons formerly; but that I deny, as an increase of sixteen per cent. in the rate of pay does not counterbalance a depreciation of twenty-five per cent. in the value of money. Unless the new warrant, should it ever see the light, secures promotion to assistant-surgeons at about twelve years' service, it will still leave the bulk of the department dissatisfied; and no mere change of title can be looked on as an equivalent.

I am, Sir, yours, \&c.,

August, 1872.

A SUBaLtern Doctor。

\section{UNION OFFICERS' (IRELAND) SUPER- ANNUATION ACT.}

To the Eator of The Lancert.

Sir,-In The Lancer of the 1st June last you were good enough to publish the Union Officers' (Ireland) Superannuation Bill, and at the same time to draw attention to an amendment which I had suggested, by which dispenstry medical officers should have their emoluments from registration and vaccination included in the calculation of the amount of their superannuation. I an happy to inform you that, owing to the indefatigable exertions of Sir Dominic Corrigan, the amendment has been substiantially inserted in the Act now the $35 \& 36$ Vict. cap. 89 I forward you the clause, as I think it will interest many of your Irish readers.

I remain, Sir, yours, \&c.,

D. Torfr T. MaUnsert,

Hon. Sec. Irish Poor-law Med. Officers' Association. Harrington-terrace, Dublin, Ang. 26th, 1872.

Union Officers' (Ireland) Superannuation.

$35 \& 36$ Vict. cap. 89.-Clause 2: "The superintendent registrar of births, deaths, and marriages, appointed in any union in Ireland, being also clerk of such union and the registrar of births, deaths, and marriages,* sball be

* In Ireland the dispensary medical officer is, ex offcio, the reg.strar of births, deaths, and Roman Catholic marriages. 
deemed officers within the operation of the recited Act, and in computing the salary of any officer of a union under the recited Act and this Act, the amount of the emoluments of his office on the average of the three years concluded in the last preceding quarter may be taken into calcuation by the guardians, and the allowance awarded in respect thereof under the recited Act and this Act shall be charged upon the rates of the union at large."

\section{BRIGHTON.}

(From our own Correspondent.)

\section{THE BRITISH ASSOCIATION.}

Althodgr the report of the meeting of the British Association for the Advancement of Science was apparently concluded in your last number, I venture to think that a résumé of further papers read before the meeting will prove sufficiently interesting to warrant insertion.

Dr. Burdon Sanderson communicated some observations "On the Rbythmical Variation of Arterial Pressure." $\mathrm{He}$ pointed out the rhythmical irregularities observable in the pulsation of certain animals, stating that the periods of fast beating correspond with inspiration, and that the periods of slow beating correspond with expiration, and explaining how this is recorded by a graphic method. Discussing the question of the relation of these phonemena, he showed that, when the muscles are subjected to paralysis, so that respiration almost ceases, there is no variation in pulsation, whence he concluded that the phenomena in question are not related as cause and effect, but are results of the same cause.

Mr. A. H. Garrod followed with a paper "On Pulse Frequency, and the forces which vary it." He related some experiments to show that the rapidity of the pulse varies inversely as the resistance to the flow of blood from the arteries; that variations in the amount of blood in circulation do not vary the rapidity of the pulse, and consequently that the pulse rate is not dependent on blood-pressure, as many suppose.

"Experiments relating to the Coagulation of the Blood" were described by Mr. E. A. Schafer, from which he drew the following conclusions: That frog's blood, especially if taken in the winter, exhibits but very little tendency to coagulate, with the exception of the portion in immediate contact with a foreign surface; that when apparently coagulated throughout, the central portions are very apt to remain fluid, and to impart coagulability to the expressed serum; that the clot, when formed frequently, tends to at. tain a relatively very small bulk; and, finally, that this diminution in bulk is due to contraction merely-not reliquefaction of the fibrine.

A paper of considerable practical interest was read in the Fconomic section by Dr. Edward Smith, entitled "The Economic and Nutritive Value of the three principal Preserved Foods-viz., Preserved Milk, Preserved Meat, and Liebig's Extract of Meat." Our limits will not permit us to give the author's views here, but he showed that the milk was very dear to the consumer, for a $16 \mathrm{oz}$. tin, worth 1s., represented a little more than two-thirds of a pint of extracts $_{\text {s }}$ worth about $6 \frac{1}{2} d$. Concerning the meat, he mentioned what is pretty well known to everyone, regarding its mode of cooking, composition, \&c.; but it might be used in the way of a change of food, although not continuously. Liebig's extract of meat was sold as a very thick liquid in jars, and $1 \mathrm{lb}$. was said to represent $32 \mathrm{lb}$. of meat; a very large proportion, however, consisted of water, and ought to contain the soluble parts of meat; but the fibrine, the fat, the gelatine, and the albumen, were all carefully excluded. Beyond that, what was left was certainly not meat. What then was it? It was, he said, like the play of Hamlet with the part of Hamlet left out. It was meal without meat. In no sense did it represent the value of $32 \mathrm{lb}$. of meat. It was, too, extremely dear; and Baron Liebig never affirmed that it was meat or equivalent to meat. As might have been expected, a long and animated discussion followed, in which Mr. Dixon, Mr. Franklin, Dr. Webster (of Dulwich), Mr. Fellowes, Mr. Ryner, Mr. John Robertson, Dr. Tanner, and a lady took part.

In the same section a paper was read by Mr. Hyde Clark on "Polygamy as affecting Population," and the conclusion arrived at from the various statistics he quoted was that, all things being equal, the greatest number of children w uld be from the single husband and single wife. 'This would only be increased, so far as the min was concerned, by his having successive wives. This paper likewise gave rise to a very animated discussion.

Professor Rolleston, of Oxford, gave a description of the Skulls found by Canon Greenwell in the Yorkshire barrows, which, indeed, was supplemental to the Canon's paper previously referred to. There was no donbt, he remarked, that in Eugland along-headed race preceded the short-headed race, and the skulls that had come into bis hands seemed to bear out that theory. He did not believe that these skulls belonged to people who were represented in Yorkshire or in England at the present day.

Mr. Boyd Dawkins, who had reported upon the other bones found in these barrows, said that they implied that this long-headed race was a pastoral people. The researches of Brnca and Dr. Thurnam established the fact that this class of skull was more intimately related to the Basque crania than to those of any other people.

"The Mechanism of the Changes of Colour in Fishes and Crustacea" was the subject of a paper in French, by M. Georges Pouchet, and a series of experiments upon the optic nerve went to show that the change of colour was dependent upon impressions received by the nervous system through the organs of vision. These changes of colour do not occur in blind fishes, nor in other fishes in whom the optic nerve has been divided.

Some other subjects of interest were "The Human Voice as a Musical Instrument," by Mr. G. Vandaleur Lee; "New Derivatives from Morphine and Codeine," by Mr. E. A. Wright; "On Instinct," by Mr. D. A. Spalding; and "On the Scientific Value of Beauty," by Mr. F. T. Mott. With regard to this last paper, which was in relation to the doctrines of Mr. Darwin and Mr. Galton, the author maintained the hypothesis that physical beauty in the organic world is a mark of maturity of climax and of perfected function; and that degrees of beauty are measures of the development of functions, and may be turned to account as such in scientific investigations. $\mathrm{He}$ proceeded to illustrate this theory by the phenomena of snow crystals, in which a process analogous to the development of organic form might be studied without the complexity of organic conditions.

Dr. B. W. Richardson read a "Report on the Physiological Action of Organic Chemical Compounds," which formed the ninth of a similar kind communicated to the Association. The first section of the report treated of the consideration of the effects of various organic chemical substances upon the circulation through the lungs. Some agents, it was shown, produce a form of paralysis of the bloodvessels of the lungs leading to congestion of those organs. Other classes of agents were noticed to have an opposite effect upon the minute circulation. These increased the resistance of the vessels as well as the tension, and by so doing opposed, and even sometimes overpowered, the heart. In the next part of his report he described a series of new researches he had carried out with various representatives of the organic class. He commenced with observations on the action of hydrogen, then in turn of oxalic ether, carbonic ether, ethyl-methyl ether, bromine, a new series of organic bromides and mandragora. In this section of the report the new ether, called ethyl-methyl, was defined as a safe and excellent anæsthetic, that might be used with success for preventing the pain of surgical operations; and the element bromine was shown to be an active destroyer of animal tissues, and in this way had been found of service in the treatment of cancer. In the present year the author had reinvestigated the action of mandragora, and had found that the ancient views of its potency were correct; a wine or tincture would induce a comparatively safe and insensible sleep, during which pain could not be excited, and that a large dose would produce a long sleep, resembling very closely death itself. The final part of the report sugursted new lines of research, based on what had been alreddy observed.-Dr. Sanderson, in the course of some observations, said that Dr. Richardson deserved the deepest gratiturle of the Association and of the public for his extraordinary labours and interesting researches.

Mr. Lowne read a report "On Terato-embryological Inquiries," in which he described the apparatus he had used 